\title{
Symmetrical and Asymmetrical Cyclopropenones: Synthesis and Study of Their Chemical Reactivity
}

\author{
Klimova Elena ${ }^{a}$, Klimova Tatiana ${ }^{a}$, Lijanova Irina ${ }^{b}$, Domínguez Chávez Jorge ${ }^{b}$, Hernández Ortega \\ Simon $^{\mathrm{b}}$, Méndez Iturbide Daniel ${ }^{\mathrm{c}}$ and Martínez García Marcos*, \\ ${ }^{a}$ Universidad Nacional Autónoma de México, Facultad de Química, Cd. Universitaria, Coyoacán, C.P. 04510, México \\ D.F., México \\ ${ }^{b}$ Universidad Nacional Autónoma de México. Instituto de Química, Cd. Universitaria, Coyoacán, C.P. 04510, México \\ D.F., México \\ ${ }^{c}$ Universidad Autónoma de Tlaxcala, Facultad de Ciencias de la Salud, San Pablo del Monte, C.P. 90920, Tlaxcala, \\ México
}

\begin{abstract}
Symmetrical and asymmetrical cyclopropenones with diferrocenyl, diaryl and aryl-ferrocenyl substituents were obtained and their chemical behavior was studied. 1-Ethoxy-2,3-diarylcyclopropenylium terafluoroborate selectively reacts with $\mathrm{MeLi}, n$-BuLi with formation of the 3,3-dialkyl-1,2-diarylcyclopropenes. The structures of 2,3-bis(4methoxyphenyl) cyclopropenone (10), 2-ferrocenyl-3-(4-methoxyphenyl) cyclopropenone (11), 2-ferrocenyl-3(naphthalen-1-yl) cyclopropenone (14) and 3,3-dimethyl-1,2-dianysol cyclopropene 19a were confirmed by X-ray crystallographic analysis.
\end{abstract}

Keywords: Cyclopropenone, ferrocene, cyclopropenium cation, cyclopropene.

The first cyclopropenilium cation, namely triphenylcyclopropenium, was synthesized and described by Breslow and coworkers in 1957 [1], and shortly after that the corresponding diphenylcyclopropenone was obtained [2]. Nowadays, numerous investigations have been carried out with this class of cations [3], and in the last years they were prepared by various routes [3-8].

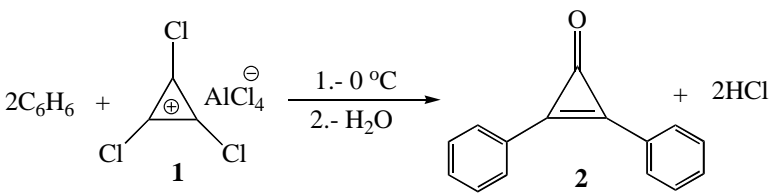

Equation 1.

The diarylcyclopropenone $\mathbf{2}$ was obtained after hydrolysis of the products of alkylation obtained by the reaction of benzene or benzene derivatives with trichloro cyclopropenium tetrachloroaluminate (1) (Equation 1) [6]. Further study of this reaction showed that it takes place stepwise; at low temperature, a single chlorine atom in the $\mathrm{C}_{3} \mathrm{Cl}_{3}{ }^{+}$ion is replaced, whereas at room temperature, a mixture of monoand disubstituted products is obtained [6]. Trisubstitution is not normally observed. From the point of view of the mechanism, the reaction shown in equation $\mathbf{1}$ is a FriedelCrafts alkylation, involving electrophilic substitution on the carbon of the benzene ring, and generally leads to the formation of symmetrical diarylcyclopropenones. The common reagents for this reaction are aromatic hydrocarbons bearing weakly activating groups (alkyl) or weakly deactivating substituents (halogen).

*Address correspondence to this author at the Universidad Nacional Autónoma de México. Instituto de Química, Cd. Universitaria, Coyoacán, C.P. 04510, México D.F., México; E-mail: margar@servidor.unam.mx
Diarylcyclopropenone 2 was found to be able to react with several chemical reagents such as amines, hydrazines, alcohols, thiols, organometallics and diazo-compounds [8].

The synthesis of diferrocenylcyclopropenone 3 has been performed in our group [9]. It was found that the reactions of 3 with ethyl- and benzylmagnesium chlorides afforded not only 3,3-diethyl- and 3,3-dibenzyl-1,2-diferrocenylcyclopropenes $\mathbf{4 a}$ and $\mathbf{4 b}$, respectively (Equation 2), but also products of nucleophilic opening of the three-membered ring $\mathbf{5 a}, \mathbf{b}$ and $\mathbf{6 a}, \mathbf{b}$. This result was attributed to the presence of two ferrocenyl groups in the structure of the compound $\mathbf{3}$ making its chemical behavior different from the reported previously for the diaryl cyclopropenones.

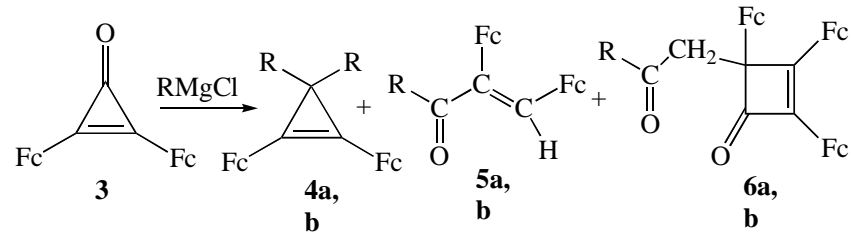

$\mathrm{R}=-\mathrm{CH}_{2} \mathrm{Ph}(\mathrm{a}) ;-\mathrm{CH}_{2}-\mathrm{CH}_{3}(\mathrm{~b})$

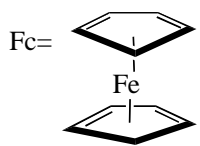

Equation 2.

In contrast to symmetrical diaryl- or diferrocenyl cyclopropenones, their asymmetrical analogs with the aryl and ferrocenyl sustituents in the same molecule have not been synthesized and studied up to now. At the same time, the influence of the ferrocenyl fragment on regio- and stereo- 

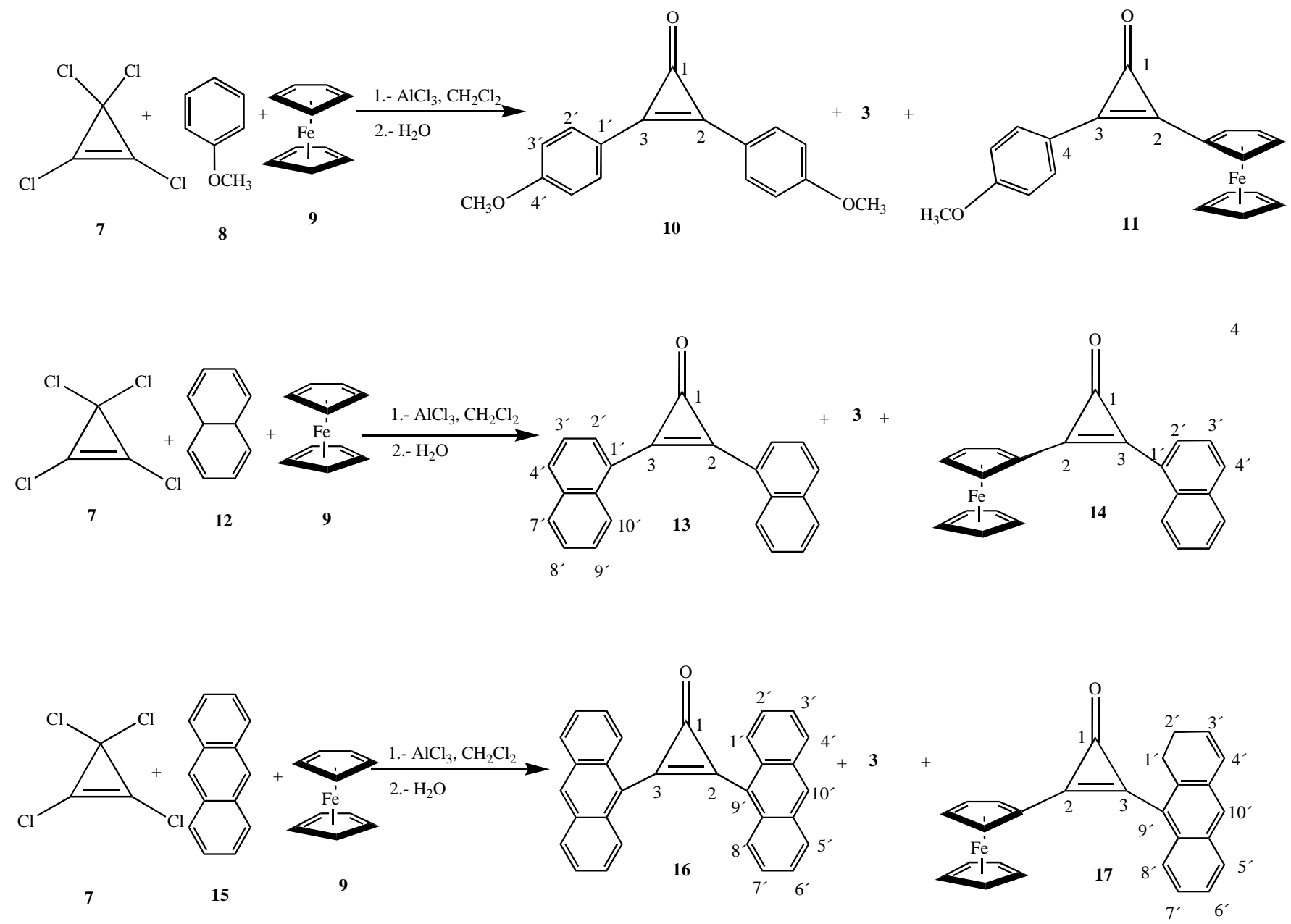

Scheme 1. Synthesis of symmetrical and asymmetrical cyclopropenones.

chemistry of aryl-ferrocenyl cyclopropenones and its chemical properties deserve to be studied.

In the present work, we report the synthesis of symmetrical diaryl and asymmetrical aryl-ferrocenyl cyclopropenones and the behavior of the 1-ethoxy-2,3-diarylcyclopropenium cation in the reactions with organolithium reagents.

\section{RESULTS AND DISCUSSION}

The cyclopropenones $3,10,11,13,14,16$ and 17 were obtained from tetrachlorocyclopropene $\mathbf{7}$ and the mixtures of ferrocene-anisole, ferrocene-naphthalene and ferroceneanthracene in anhydrous $\mathrm{CH}_{2} \mathrm{Cl}_{2}$ using catalytic amounts of aluminum chloride.

The following signals were observed in the ${ }^{1} \mathrm{H}$ NMR spectrum of compound 10: one singlet at $\delta 3.91$ for the methoxy groups and two doublets at $\delta 7.06$ and 7.93 for the aryl groups. In the ${ }^{1} \mathrm{H}$ NMR spectrum of the asymmetrical cyclopropenone (11) were observed the signals of the methoxy group (one singlet at $\delta 3.90$ ), the ferrocenyl group (three characteristic signals at $\delta 4.22,4.59$ and 4.89) and the aryl group (two doublets at $\delta 7.06$ and 8.84).

Crystals of 2,3-bis(4-methoxyphenyl) cyclopropenone (10) and 2-ferrocenyl-3-(4-methoxyphenyl) cyclopropenone (11) suitable for X-ray crystallographic studies were ob- tained by crystallization from hexane. Fig. (1 and 2) show the crystal structures of the compounds $\mathbf{1 0}$ and $\mathbf{1 1}$.

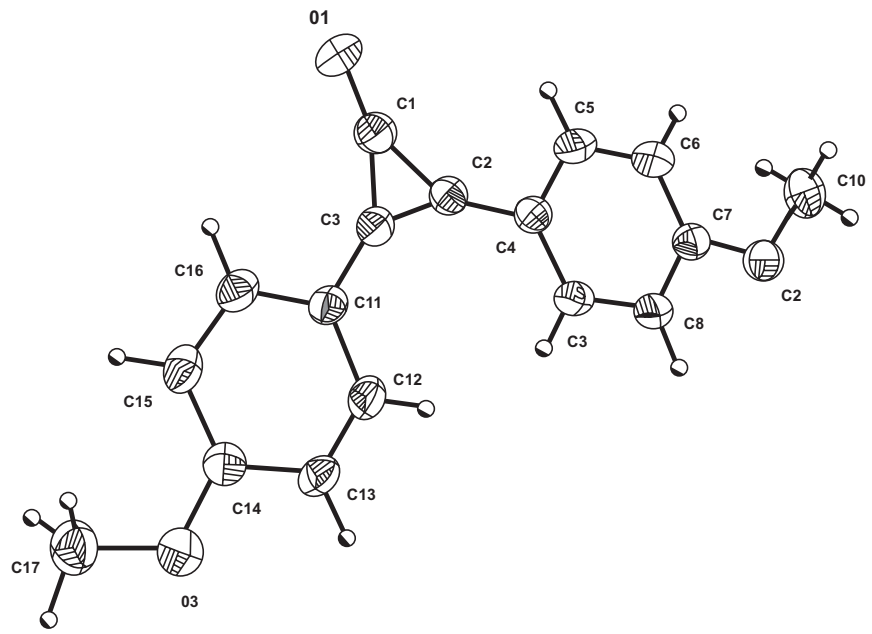

Fig. (1). Crystal structure of the symmetrical compound (10). Selected bond lengths $[\AA]$ : $\mathrm{C}(1)-\mathrm{C}(2)=1.412, \mathrm{C}(1)-\mathrm{C}(3)=1.408, \mathrm{C}(2)$ $\mathrm{C}(3)=1.356, \mathrm{C}(1)-\mathrm{O}(1)=1.223$. Selected bond angles $\left({ }^{\circ}\right)$ : $\mathrm{C}(3)$ $\mathrm{C}(1)-\mathrm{C}(2)=57.48, \mathrm{C}(3)-\mathrm{C}(2)-\mathrm{C}(1)=61.11, \mathrm{C}(2)-\mathrm{C}(3)-\mathrm{C}(1)=61.41$. 
The following signals were observed in the ${ }^{1} \mathrm{H}$ NMR spectrum of the compound 13: one doublet assigned to the naphthyl group at $\delta 8.94$ with a coupling constant $J=8.5 \mathrm{~Hz}$ due to the proton in the position $7^{\prime}$, three doublets at $\delta 8.38$, 8.18 and 7.90, all with coupling constants $J=7.0 \mathrm{~Hz}$ for the protons in the positions $2^{\prime}, 4^{\prime}$ and $10^{\prime}$, respectively, and two multiplets at $\delta 7.85$ and 7.65 due to the protons in the positions $3^{\prime}, 8^{\prime}$, and $10^{\prime}$. In the ${ }^{13} \mathrm{C}$ NMR spectrum of this compound, the most important signals observed were at $\delta 146$ corresponding to the $s p^{2}$ carbon of the cyclopropene and at $\delta$ 155.5 which is the signal characteristic for the carbonyl group.

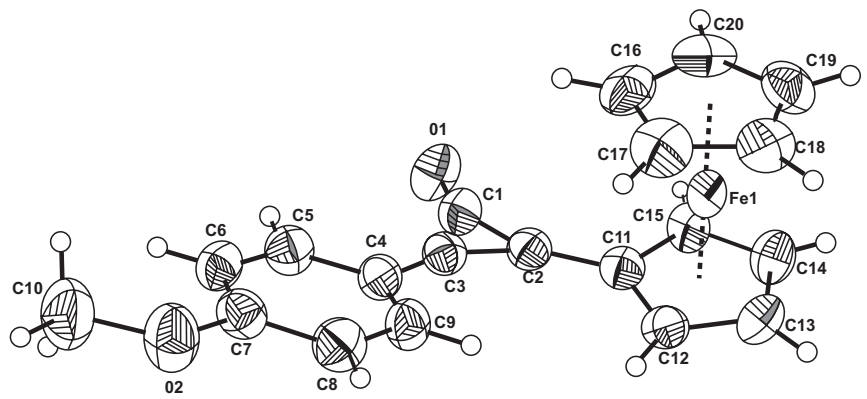

Fig. (2). Crystal structure of the asymmetrical compound (11). Selected bond lengths $[\AA]$ : $C(1)-C(2)=1.412, C(1)-C(3)=1.399$, $\mathrm{C}(2)-\mathrm{C}(3)=1.362, \mathrm{C}(1)-\mathrm{O}(3)=1.223$. Selected bond angles $\left({ }^{\circ}\right): \mathrm{C}$ (3) $-\mathrm{C}(1)-\mathrm{C}(2)=57.8, \mathrm{C}(3)-\mathrm{C}(2)-\mathrm{C}(1)=60.7, \mathrm{C}(2)-\mathrm{C}(3)-\mathrm{C}(1)=61.5$.

In the case of the asymmetrical compound (14), in the ${ }^{1} \mathrm{H}$ NMR spectrum were observed the signals of both ferrocenyl (three characteristic signals at $\delta 4.22,4.59$ and 4.89) and naphthyl (at $\delta 7.06,7.84,7.23-7.42)$ groups. Crystals of 2ferrocenyl-3-(naphthalen-1-yl) cyclopropenone (14) obtained by crystallization from hexane were studied by X-ray diffraction of monocrystal (Fig. 3).

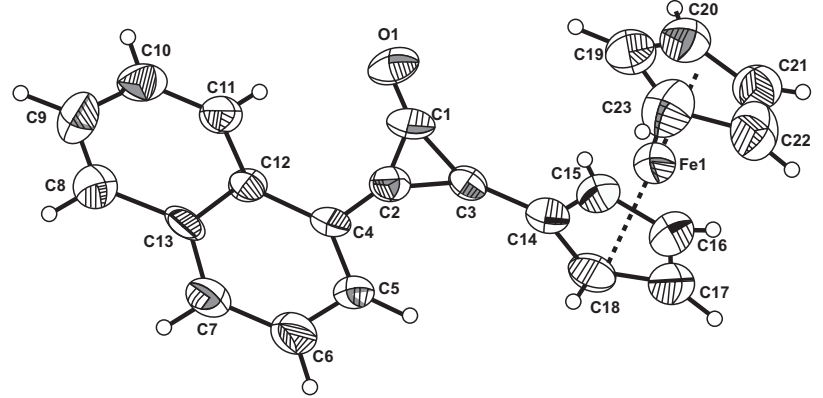

Fig. (3). Crystal structure of the asymmetrical cyclopropenone (14). Selected bond lengths $[\AA]$ : $C(1)-C(2)=1.416, C(1)-C(3)=1.409$, $\mathrm{C}(2)-\mathrm{C}(3)=1.374, \mathrm{C}(1)-\mathrm{O}(1)=1.226$. Selected angles $\left({ }^{\circ}\right): \mathrm{C}(3)-$ $\mathrm{C}(1)-\mathrm{C}(2)=58.2, \mathrm{C}(3)-\mathrm{C}(2)-\mathrm{C}(1)=60.6, \mathrm{C}(2)-\mathrm{C}(3)-\mathrm{C}(1)=61.2$.
In the ${ }^{1} \mathrm{H}$ NMR spectrum of compound $\mathbf{1 6}$ the following signals assigned to the anthracenyl group were observed: one singlet at $\delta 8.86$ due to the two protons in the positions $10^{\circ}$; one doublet at $\delta 8.41$ with a coupling constant $J=6.9 \mathrm{~Hz}$ for the protons in the positions $1^{\prime}$ and $8^{\prime}$; double of doublets at $\delta$ 8.1 with coupling constants $J=6.4 \mathrm{~Hz}$ ascribed to the protons in the positions $4^{\prime}$ and $5^{\prime}$; one multiplet at $\delta 7.4$ due to the protons in the positions $3^{\prime}, 6^{\prime}$ and $2^{\prime}, 7^{\prime}$. In the ${ }^{13} \mathrm{C}$ NMR spectrum of compound $\mathbf{1 6}$ were observed the signals characteristic for the anthracene moiety at $\delta 111.3-134.8$, the signal due to the $s p^{2}$ carbons $\mathrm{C}=\mathrm{C}$ of the cyclopropene ring at $\delta 148.1$, and the most important signals of the quarternary carbons of the cyclopropene at $\delta 156.7$ and the signal characteristic for the carbonyl group at $\delta 155.5$. For the asymmetrical cyclopropenone 17, in the ${ }^{1} \mathrm{H}$ NMR spectrum were observed the signals of the ferrocenyl (three characteristic signals at $\delta 4.24,4.66$ and 5.01) and the anthracenyl group (two doublets at $\delta 7.06$ and 7.84 with coupling constants $J=7.1$ $\mathrm{Hz}$ and $J=1.3 \mathrm{~Hz}$, respectively); also two sets of multiplets were observed at $\delta 7.9-8.1$ and at 8.32 due to the protons in the positions $1^{\prime}, 4^{\prime}, 5^{\prime}$ and $8^{\prime}$.

XRD studies of compounds 10, 11 and 14 showed that the presence of two large and heavy substituents in their molecules leads to the distortion of the cyclopropenone structure and to enlargement of the internal angles in the positions 2 and 3 .

Treatment of diarylcyclopropenone with triethyloxonium tetrafluoroborate in benzene and precipitation of the resulting product with diethyl ether affords crystalline 1-ethoxy-2,3diarylcyclopropenylium tetrafluoroborate 18 (Equation 3).

However, the cyclopropenylium tetrafluoroborate (18) was unstable and its characterization by NMR spectroscopy was not possible.

The action of alkyllithium reagents on diferrocenylcyclopropenylium tetrafluoroborate (18), affords the corresponding 1,2,3-substituted cyclopropenes (19a,b) (Equation 4).

The following signals were observed in the ${ }^{1} \mathrm{H}$ NMR spectrum of compound 19a: one singlet at $\delta 3.62$ due to the methyl groups, one singlet at $\delta 3.85$ for the methoxy groups and two doublets at $\delta 6.97$ and 7.53 for the protons of the aryl groups.

In the ${ }^{1} \mathrm{H}$ NMR spectrum of the 3,3-di-(n-butyl)- 1,2bis(4-methoxyphenyl) cyclopropene 19b were observed: one multiplet at $\delta 0.79$ due to the methyl groups, two multiplets at $\delta 1.19$ and 1.81 assigned to the methylene groups, one singlet at $\delta 3.84$ due to the methoxy group, and two doublets at $\delta 6.95$ and 7.55 due to the aryl groups.

The crystal structure of the 1,2-diaryl-3,3-dimethylcyclopropene (19a) shown in Fig. (4) was established by X-ray<smiles>CCCCCCCCCC1=C(c2ccc(OC)cc2)C(OCC)=C1c1ccc(OC)cc1</smiles>

Equation 3. 


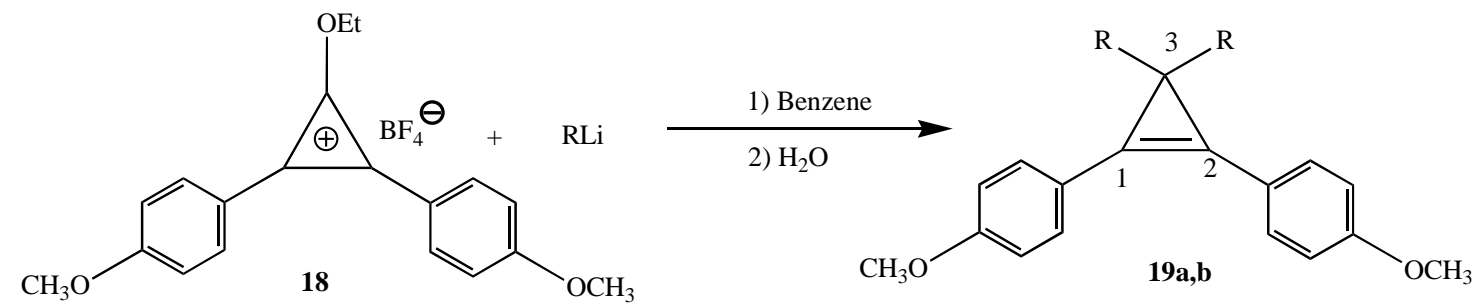

Equation 4.
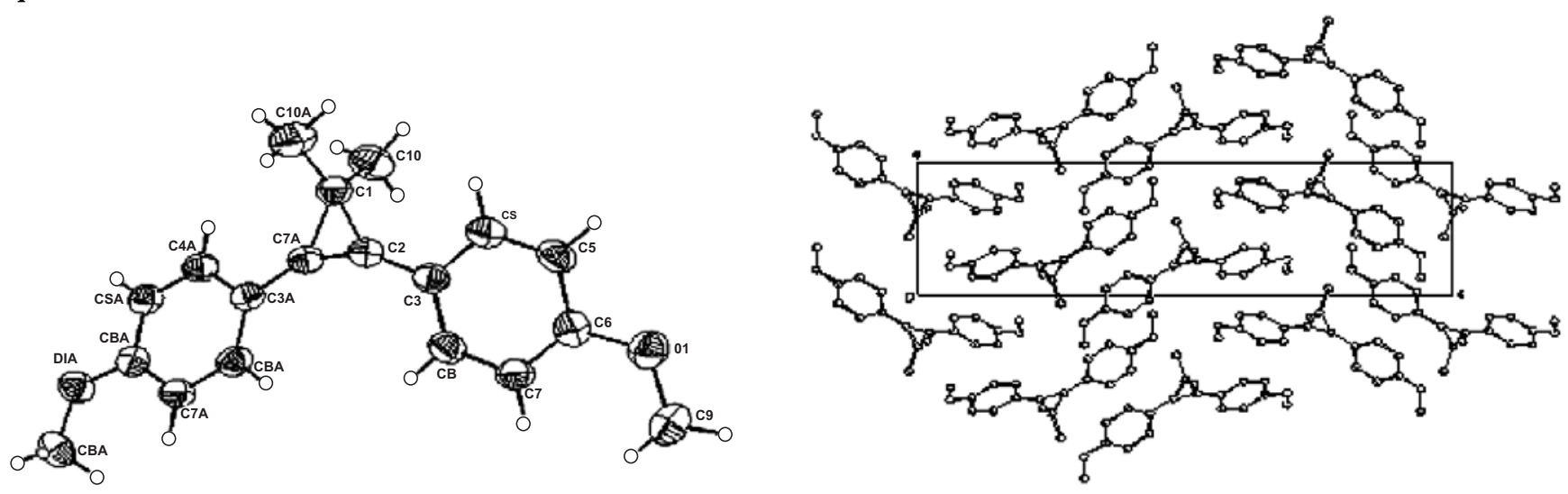

Fig. (4). Crystal structure and crystal packing of the compound (19a). Selected bond lengths $[\AA]$ : $C(1)-C(2 A)=1.501, C(1)-C(2)=1.501$, $\mathrm{C}(2)-\mathrm{C}(3)=1.446, \mathrm{C}(2)-\mathrm{C}(2 \mathrm{~A})=1.301, \mathrm{C}(1)-\mathrm{C}(10 \mathrm{~A})=1.521$. Selected bond angles $\left({ }^{\circ}\right)$ : $\mathrm{C}(2)-\mathrm{C}(1)-\mathrm{C}(2 \mathrm{~A})=51.40, \mathrm{C}(2 \mathrm{~A})-\mathrm{C}(2)-\mathrm{C}(1)=64.30$, $\mathrm{C}(1)-\mathrm{C}(2)-\mathrm{C}(2 \mathrm{~A})=64.30$.

diffraction analysis and is in line with the ${ }^{1} \mathrm{H}$ NMR spectroscopy results described above.

\section{CONCLUSIONS}

The use of electron-donating substituents like ferrocene, 4-methoxy-benzene, naphthalene and anthracene in the synthesis of symmetrical or asymmetrical cyclopropenones allows preparation of compounds that are stable for long periods of time. The presence of heavy substituents in the cyclopropenones leads to the distortion of the small cycle. In agreement with our studies, the best yields were obtained with ferrocene. This could be due to its stronger electrondonating properties in comparison with the other aromatic systems studied.

\section{EXPERIMENTAL SECTION}

\section{General Information}

Infrared (IR) spectra were recorded on a Nicolet FT-IR Magna 700 Spectrometer. ${ }^{1} \mathrm{H}$ - and ${ }^{13} \mathrm{C}$ - NMR spectra for solutions in $\mathrm{CDCl}_{3}$ were collected on a Varian Unity operating at 300 and $75 \cdot \mathrm{MHz}$, respectively. For both ${ }^{1} \mathrm{H}$ and ${ }^{13} \mathrm{C}$, chemical shifts are expressed in ppm relative to tetramethylsilane $\left(\mathrm{Me}_{4} \mathrm{Si} \delta 0.00\right)$ as the internal standard. Column chromatography was carried out on alumina (Brockmann activity III). Elemental analyses were performed at Galbraith Laboratories, INC. Knoxville. USA. FAB+ mass spectra were taken with a JEOL JMS AX505 HA mass spectrometer. Unit cell parameters and intensities of reflections were measured on a Siemens $\mathrm{P} 4 / \mathrm{Pc}$ diffractometer at room temperature.

\section{General Procedure for the Synthesis of Cyclopropenones}

$\mathrm{AlCl}_{3}(0.67 \mathrm{~g}, 5 \mathrm{mmol})$ was added by portions to a solution of one of the compounds $\mathbf{8 , 1 2}, 15(23.0 \mathrm{mmol})$ and ferrocene 9 (23.0 $\mathrm{mmol})$ and tetrachlorocyclopropene (23.0 mmol) in anhydrous $\mathrm{CH}_{2} \mathrm{Cl}_{2}(200 \mathrm{~mL})$ under continuous stirring for $30 \mathrm{~min}$. The stirring was continued for another 90 min at room temperature, then the mixture was poured in cold water $(200 \mathrm{~mL})$. The organic layer was separated, washed with water $(2 \times 50 \mathrm{~mL})$ and dried with $\mathrm{MgSO}_{4}$. After the solvent was distilled off in vacuo, the residue was chromatographed on $\mathrm{Al}_{2} \mathrm{O}_{3}$ using a hexane- $\mathrm{CH}_{2} \mathrm{Cl}_{2}$ (3:1) mixture as eluent.

\section{Reaction of Tetrachlorocyclopropene 7 with Fc-H and p- $\mathrm{CH}_{3}-\mathrm{O}-\mathrm{C}_{6} \mathrm{H}_{5}$}

\section{2,3-diferrocenylcyclopropenone (3)} $\%)$.

For spectral data see ref. [10], yield $3.9 \mathrm{~g}, 9.5 \mathrm{mmol}$ (41.3

\section{2,3-bis(4-methoxyphenyl)cyclopropenone (10)}

Yield $2.1 \mathrm{~g}$ (34.8\%), white powder, m.p. 153-155 ${ }^{\circ} \mathrm{C}$. FTIR (pellet, $\mathrm{KBr}, \mathrm{cm}^{-1}$ ): 511, 754, 830, 1017, 1168, 1256, 1510, 1602, 1846. UV-Vis $\left(\mathrm{CH}_{2} \mathrm{Cl}_{2}, \mathrm{~nm}\right) \lambda_{\max }: 255,271,323$, 334, 342. ${ }^{1} \mathrm{H}$ NMR $\left(300 \mathrm{MHz}, \mathrm{CDCI}_{3}\right), \delta_{\mathrm{H}}(\mathrm{ppm}): 3.91(\mathrm{~s}$, $\left.6 \mathrm{H}, \mathrm{OCH}_{3}\right), 7.06\left(\mathrm{~d}, 4 \mathrm{H}, \mathrm{C}_{6} \mathrm{H}_{4}, J=7.1 \mathrm{~Hz}\right), 7.93(\mathrm{~d}, 4 \mathrm{H}$, $\left.\mathrm{C}_{6} \mathrm{H}_{4}, J=7.3 \mathrm{~Hz}\right) .{ }^{13} \mathrm{C} \mathrm{NMR}\left(75 \mathrm{MHz}, \mathrm{CDCl}_{3}\right), \delta_{\mathrm{C}}(\mathrm{ppm})$ : $55.5\left(\mathrm{OCH}_{3}\right), 114.7$ (Ar), $122.3\left(\mathrm{C}_{\mathrm{ipso}}\right), 126.8$ (Ar), 160.1 $\left(\mathrm{C}_{\mathrm{ipso}}\right), 155.2(\mathrm{C}=\mathrm{C}), 162,8(\mathrm{C}=\mathrm{O})$. EM: m/z 267. Calc. for $\mathrm{C}_{17} \mathrm{H}_{14} \mathrm{O}_{3}$ : C, 76.76; H, 5.28 (\%). Found: C, 76.67; H, 5.30. 


\section{2-ferrocenyl-3-(4-methoxyphenyl)cyclopropenone (11)}

Yield $1.22 \mathrm{~g}(15.2 \%)$, orange powder, m.p. $120-121{ }^{\circ} \mathrm{C}$. FTIR (pellet, $\mathrm{KBr}, \mathrm{cm}^{-1}$ ): 512, 756, 833, 1019, 1178, 1286, 1521, 1602, 1846. UV-Vis $\left(\mathrm{CH}_{2} \mathrm{Cl}_{2}, \mathrm{~nm}\right) \lambda_{\max }: 225,261,333$, 342. ${ }^{1} \mathrm{H}$ NMR $\left(300 \mathrm{MHz}, \mathrm{CDCI}_{3}\right), \delta_{\mathrm{H}}(\mathrm{ppm}): 3.90(\mathrm{~s}, 3 \mathrm{H}$, $\left.\mathrm{OCH}_{3}\right), 4.22\left(\mathrm{~s}, 5 \mathrm{H}, \mathrm{C}_{5} \mathrm{H}_{5}\right), 4.59\left(\mathrm{~s}, 2 \mathrm{H}, \mathrm{C}_{5} \mathrm{H}_{4}\right), 4.89(\mathrm{~s}, 2 \mathrm{H}$, $\left.\mathrm{C}_{5} \mathrm{H}_{4}\right), 7.06\left(\mathrm{~d}, 2 \mathrm{H}, \mathrm{C}_{6} \mathrm{H}_{4}, J=7.1 \mathrm{~Hz}\right), 7.84\left(\mathrm{~d}, 2 \mathrm{H}, \mathrm{C}_{6} \mathrm{H}_{4}, J=\right.$ $7.6 \mathrm{~Hz}),{ }^{13} \mathrm{C}$ NMR $\left(75 \mathrm{MHz}, \mathrm{CDCl}_{3}\right), \delta_{\mathrm{C}}(\mathrm{ppm}): 55.5\left(\mathrm{CH}_{3}\right)$, $64.6\left(\mathrm{Fc}_{\text {ipso }}\right) 70.0\left(\mathrm{C}_{5} \mathrm{H}_{5}\right), 71.5\left(\mathrm{C}_{5} \mathrm{H}_{4}\right), 72.2\left(\mathrm{C}_{5} \mathrm{H}_{4}\right), 114.7$ $\left(2 \mathrm{C}, \mathrm{C}_{6} \mathrm{H}_{4}\right), 117.8\left(\mathrm{Ar}_{\text {ipso }}\right), 132.7(\mathrm{Ar}), 141.5(\mathrm{C}=\mathrm{C}), 147.1$ $(\mathrm{C}=\mathrm{C}), 153.6\left(\mathrm{Ar}_{\text {ipso }}\right), 158.4(\mathrm{C}-\mathrm{O}), 162.3(\mathrm{C}=\mathrm{O}) . \mathrm{EM}: \mathrm{m} / \mathrm{z}$ 344. Calc. for $\mathrm{C}_{20} \mathrm{H}_{16} \mathrm{FeO}_{2}$ : C, 69.79; H, 4.69 (\%). Found: C, 69.67; H, 4.68

Reaction of tetrachlorocyclopropene 7 with Fc-H and $\mathrm{C}_{10} \mathrm{H}_{8}$

\section{Diferrocenyl cyclopropenone (3)}

Yield $1.2 \mathrm{~g}, 2.85 \mathrm{mmol}(19.1 \%)$.

\section{2,3-bis(naphthalen-1-yl)cyclopropenone (13)}

Yield $0.80 \mathrm{~g}$ (11.35\%), white crystals, m.p. $153-155^{\circ} \mathrm{C}$. FTIR (pellet, $\mathrm{KBr}, \mathrm{cm}^{-1}$ ): 519, 856, 823, 1029, 1188, 1289, 1571, 1682, 1846. UV-Vis $\left(\mathrm{CH}_{2} \mathrm{Cl}_{2}, \mathrm{~nm}\right) \lambda_{\text {max }}: 215,271,334$, 352. ${ }^{1} \mathrm{H}$ NMR $\left(300 \mathrm{MHz}, \mathrm{CDCI}_{3}\right), \delta_{\mathrm{H}}(\mathrm{ppm}): 7.65(\mathrm{~m}, 4 \mathrm{H}$, Ar), 7.85 (m, 2H, Ar), 7.90 (d, 2H, Ar, J=7.0 Hz), 8.18 (d, $2 \mathrm{H}, \mathrm{Ar}, J=7.0 \mathrm{~Hz}), 8.38(\mathrm{~m}, 2 \mathrm{H}, \mathrm{Ar}, J=7.0 \mathrm{~Hz}), 8.94$ (d, $2 \mathrm{H}$, $\mathrm{Ar}, J=8.5 \mathrm{~Hz}$,). ${ }^{13} \mathrm{C} \mathrm{NMR}\left(75 \mathrm{MHz}, \mathrm{CDCl}_{3}\right), \delta_{\mathrm{C}}(\mathrm{ppm}): 112.3$ (Ar), 125.2 (Ar), 126.5 (Ar), 127.2 (Ar), 128.3 (Ar), 128.6 (Ar), 129.9 (Ar), 133.2 (Ar), 133.7 (Ar ipso $\left._{\text {ips }}\right), 133.8\left(\mathrm{Ar}_{\mathrm{ipso}}\right)$, 146.4 (C=C), $155.6(\mathrm{C}=\mathrm{O})$. EM: m/z 306. Calc. for $\mathrm{C}_{23} \mathrm{H}_{14} \mathrm{O}$ : C, 90.17; H, 4.61 (\%). Found: C, 90.18; H, 4.59.

\section{2-ferrocenyl-3-(naphthalen-1-yl) cyclopropenone (14)}

Yield $1.60 \mathrm{~g}(12.4 \%)$, orange powder, m.p. $162-163{ }^{\circ} \mathrm{C}$. FTIR (pellet, $\mathrm{KBr}, \mathrm{cm}^{-1}$ ): 520, 836, 852, 1039, 1178, 1269, $1561,1782,1856$. UV-Vis $\left(\mathrm{CH}_{2} \mathrm{Cl}_{2}, \mathrm{~nm}\right) \lambda_{\max }: 225,271,332$, 342. ${ }^{1} \mathrm{H}$ NMR $\left(300 \mathrm{MHz}, \mathrm{CDCI}_{3}\right), \delta_{\mathrm{H}}(\mathrm{ppm}): 4.24(\mathrm{~s}, 5 \mathrm{H}$, $\left.\mathrm{C}_{5} \mathrm{H}_{5}\right), 4.66\left(\mathrm{~s}, 2 \mathrm{H}, \mathrm{C}_{5} \mathrm{H}_{4}\right), 5.01\left(\mathrm{~s}, 2 \mathrm{H}, \mathrm{C}_{5} \mathrm{H}_{4}\right), 7.06(\mathrm{~m}, 2 \mathrm{H}$, $\left.\mathrm{C}_{10} \mathrm{H}_{7}\right), 7.84\left(\mathrm{~m}, 2 \mathrm{H}, \mathrm{C}_{10} \mathrm{H}_{7}\right)$, 7.23-7.42 (m, 3H, $\left.\mathrm{C}_{10} \mathrm{H}_{7}\right) .{ }^{13} \mathrm{C}$ NMR $\left(75 \mathrm{MHz}, \mathrm{CDCl}_{3}\right), \delta_{\mathrm{C}}(\mathrm{ppm}): 64.9\left(\mathrm{Fc}_{\mathrm{ipso}}\right) 71.0\left(\mathrm{C}_{5} \mathrm{H}_{5}\right)$, $71.5\left(\mathrm{C}_{5} \mathrm{H}_{4}\right), 72.2\left(\mathrm{C}_{5} \mathrm{H}_{4}\right), 114.7(\mathrm{Ar}), 127.6(\mathrm{Ar}), 129.7(\mathrm{Ar})$, 130.3 (Ar), 132.7 (Ar), $141.5(\mathrm{C}=\mathrm{C}), 147.1 \quad(\mathrm{C}=\mathrm{C}), 151.4$ (Ar), $153.6\left(\mathrm{Ar}_{\text {ipso }}\right), 158.4\left(\mathrm{Ar}_{\text {ipso }}\right), 162.36(\mathrm{C}=\mathrm{O}) . \mathrm{EM}: \mathrm{m} / \mathrm{z}$ 364. Calc. for $\mathrm{C}_{23} \mathrm{H}_{16} \mathrm{FeO}$ : C, 75.84; H, 4.43 (\%). Found: $\mathrm{C}$, 75.82; H, 4.32.

Reaction of tetrachlorocyclopropene 7 with Fc-H and $\mathrm{C}_{14} \mathrm{H}_{10}$

\section{Diferrocenylcyclopropenone (3)}

Yield $1.6 \mathrm{~g}(16.5 \%)$.

\section{2,3-bis(anthracen-9-yl)cyclopropenone (16)}

Yield $0.98 \mathrm{~g}$ (10.5\%), white powder, m.p. $169-170{ }^{\circ} \mathrm{C}$. FTIR (pellet, $\mathrm{KBr}, \mathrm{cm}^{-1}$ ): 522, 839, 852, 1049, 1168, 1275, $1571,1882,1896$. UV-Vis $\left(\mathrm{CH}_{2} \mathrm{Cl}_{2}, \mathrm{~nm}\right) \lambda_{\max }: 215,261,334$, 348. ${ }^{1} \mathrm{H} \mathrm{NMR}\left(300 \mathrm{MHz}, \mathrm{CDCI}_{3}\right), \delta_{\mathrm{H}}(\mathrm{ppm}): 8.86(\mathrm{~s}, 2 \mathrm{H}$, Ar), $8.41(\mathrm{~d}, 4 \mathrm{H}, \mathrm{Ar}, \mathrm{J}=6.9 \mathrm{~Hz}), 8.10(\mathrm{~d}, 4 \mathrm{H}, \mathrm{Ar}, J=6.4 \mathrm{~Hz})$, $7.4(\mathrm{~m}, 8 \mathrm{H}, \mathrm{Ar}) .{ }^{13} \mathrm{C} \mathrm{NMR}\left(75 \mathrm{MHz}, \mathrm{CDCl}_{3}\right), \delta_{\mathrm{C}}(\mathrm{ppm})$ : 111,3 (Ar), 125,2 (Ar), 126.9 (Ar), 127.8 (Ar), 128.9 (Ar), 128.6, 130.1 (Ar), 132.2 (Ar), 133.8 (Ar ipso $), 134.8\left(\mathrm{Ar}_{\mathrm{ipso}}\right)$,
$148.1(\mathrm{C}=\mathrm{C}), 156.7 \quad(\mathrm{C}=\mathrm{O})$. $\mathrm{EM}: \mathrm{m} / \mathrm{z}$ 406. Calc. for $\mathrm{C}_{31} \mathrm{H}_{18} \mathrm{O}_{1}$ : C, 91.60; H, 4.46 (\%). Found: C, 91.61; H, 4.46

\section{2-(anthracen-9-yl)-3-ferrocenyl-cyclopropenone (17)}

Yield $1.23 \mathrm{~g}$ (13\%), orange powder, m.p. 157-158 ${ }^{\circ} \mathrm{C}$. FTIR (pellet, $\mathrm{KBr}, \mathrm{cm}^{-1}$ ): 512, 840, 853, 1047, 1166, 1274, $1571,1885,1899$. UV-Vis $\left(\mathrm{CH}_{2} \mathrm{Cl}_{2}, \mathrm{~nm}\right) \lambda_{\text {max }}: 212,261,334$, 349. ${ }^{1} \mathrm{H} \mathrm{NMR}\left(300 \mathrm{MHz}, \mathrm{CDCI}_{3}\right), \delta_{\mathrm{H}}(\mathrm{ppm}): 4.24(\mathrm{~s}, 5 \mathrm{H}$, $\left.\mathrm{C}_{5} \mathrm{H}_{5}\right), 4.66\left(\mathrm{~s}, 2 \mathrm{H}, \mathrm{C}_{5} \mathrm{H}_{4}\right), 5.01\left(\mathrm{~s}, 2 \mathrm{H}, \mathrm{C}_{5} \mathrm{H}_{4}\right), 7.06(\mathrm{~d}, 2 \mathrm{H}$, $\mathrm{Ar}, J=7.1 \mathrm{~Hz}), 7.84(\mathrm{~d}, 2 \mathrm{H}, \mathrm{Ar}, J=1.3 \mathrm{~Hz}), 7.9-8.1(\mathrm{~m}, 3 \mathrm{H}$, $\mathrm{Ar}), 8.32(\mathrm{~m}, 2 \mathrm{H}, \mathrm{Ar}) .{ }^{13} \mathrm{C}$ NMR $\left(75 \mathrm{MHz}, \mathrm{CDCl}_{3}\right), \delta_{\mathrm{C}}(\mathrm{ppm})$ : $64.6\left(\mathrm{Fc}_{\text {ipso }}\right) 72.3\left(\mathrm{C}_{5} \mathrm{H}_{5}\right), 74.5\left(\mathrm{C}_{5} \mathrm{H}_{4}\right), 75.2\left(\mathrm{C}_{5} \mathrm{H}_{4}\right), 114.7$ (Ar), 115.2 (Ar), $117.8\left(\mathrm{Ar}_{\text {ipso }}\right), 122.4(\mathrm{Ar}), 132.7$ (Ar), 136.2 (Ar), 137.5(Ar), 139.8( $\left(\mathrm{Ar}_{\mathrm{ipso}}\right), 141.5(\mathrm{C}=\mathrm{C}), 147.1(\mathrm{C}=\mathrm{C})$, $162.36(\mathrm{C}=\mathrm{O})$. EM: $\mathrm{m} / \mathrm{z}$ 414. Calc. for $\mathrm{C}_{27} \mathrm{H}_{18} \mathrm{FeO}_{1}: \mathrm{C}$, 78.28; H, 4.38 (\%). Found: C, 78.27; H, 4.38.

\section{1-ethoxy-2,3-bis(4-methoxyphenyl)cyclopropenylium fluoroborate (18)}

A solution of the triethyloxonium tetrafluoroborate in $\mathrm{CH}_{2} \mathrm{Cl}_{2}$ (1M, $\left.5.14 \mathrm{ml}, 5.14 \mathrm{mmol}\right)$ was added under stirring to a solution of 2,3-bis(4-methoxyphenyl)cyclopropenone (10) $(1.33 \mathrm{~g}, 5.0 \mathrm{mmol})$ in benzene $(50 \mathrm{ml})$. The mixture was kept at room temperature for $3 \mathrm{~h}$, then dry diethyl ether (100 $\mathrm{ml}$ ) was added. The formed precipitate was filtered off, washed on a filter with several portions of dry ether, and dried in a vacuum desiccator to give 1-ethoxy-2,3-bis(4methoxyphenyl)cyclopropenylium tetrafluoroborate (18) as a white powder, yield $1.73 \mathrm{~g}(91 \%)$.

\section{3,3-dimethyl-1,2-bis(4-methoxyphenyl)cyclopropene (19a)}

A solution of methyllithium in diethyl ether (1.6 M, 4.5 $\mathrm{ml})$ was added with stirring in an inert atmosphere to a solution of (18) $(0.27 \mathrm{~g}, 0.71 \mathrm{mmol})$ in dry benzene $(200 \mathrm{ml})$. The mixture was stirred for $3 \mathrm{~h}$ at room temperature, and then water $(100 \mathrm{ml})$ was added. The organic layer was separated, washed with water $(250 \mathrm{ml})$, the solvent was removed in vacuum, and the residue was chromatographed on alumina (hexane-diethyl ether, 3:1) to give dimethylcyclopropene (19a) as a white powder, yield $0.042 \mathrm{~g}, 0.15 \mathrm{mmol}(21 \%)$, m.p. $122-124{ }^{\circ} \mathrm{C}$. FTIR (pellet, $\mathrm{KBr}, \mathrm{cm}^{-1}$ ): 511, 754, 830, $1033,1219,1510,1604,1846,961$. UV-Vis $\left(\mathrm{CH}_{2} \mathrm{Cl}_{2}, \mathrm{~nm}\right)$ $\lambda_{\text {max }}: 240,264,332,345,351 .{ }^{1} \mathrm{H}$ NMR $\left(300 \mathrm{MHz}, \mathrm{CDCI}_{3}\right)$, $\delta_{\mathrm{H}}(\mathrm{ppm}): 1.62\left(\mathrm{~s}, 6 \mathrm{H}, \mathrm{CH}_{3}\right) ; 3.85\left(\mathrm{~s}, 6 \mathrm{H}, \mathrm{OCH}_{3}\right), 6.96(\mathrm{~d}$, $\left.4 \mathrm{H}, \mathrm{C}_{6} \mathrm{H}_{4}, J=7.2 \mathrm{~Hz}\right), 7.53\left(\mathrm{~d}, 4 \mathrm{H}, \mathrm{C}_{6} \mathrm{H}_{4}, J=7.2 \mathrm{~Hz}\right) .{ }^{13} \mathrm{C}$ NMR (75 MHz, $\left.\mathrm{CDCl}_{3}\right), \delta_{\mathrm{C}}(\mathrm{ppm}): 24.6\left(\mathrm{CH}_{3}\right), 30.2(\mathrm{C}), 55.3$ $\left(\mathrm{OCH}_{3}\right), 114.3(\mathrm{C}=$, cyclopropene $), 130.3(\mathrm{Ar}), 130.7\left(\mathrm{C}_{\mathrm{ipso}}\right)$, 131.0 (Ar). EM: m/z $280[\mathrm{M}]^{+}$Calc. for $\mathrm{C}_{19} \mathrm{H}_{20} \mathrm{O}_{2}: \mathrm{C}, 81.40$; H, 7.19 (\%). Found: C, 81.42; H, 7.19

\section{3,3-di-(n-butyl)-1,2-bis(4-methoxyphenyl)cyclo-propene (19b)}

A $2.5 \mathrm{M}$ solution of methyllithium in hexanes $(8.0 \mathrm{ml})$ was added with stirring in an inert atmosphere to a solution of (17) $(1.39 \mathrm{~g}, 5.0 \mathrm{mmol})$ in dry benzene $(200 \mathrm{ml})$. The mixture was stirred for $3 \mathrm{~h}$ at room temperature and then water $(100 \mathrm{ml})$ was added. The organic layer was separated, washed with water $(250 \mathrm{ml})$, the solvent was removed in vacuum, and the residue was chromatographed on alumina (hexane-diethyl ether, 3:1) to give dimethylcyclopropene (19b), as a white powder, yield (1.5 g, $4.12 \mathrm{mmol}, 82 \%)$, m.p. $48-49{ }^{\circ} \mathrm{C}$. FTIR (pellet, $\mathrm{KBr}, \mathrm{cm}^{-1}$ ): 511, 754, 820, 
$1030,1246,1509,1603,1846,921$. UV-Vis $\left(\mathrm{CH}_{2} \mathrm{Cl}_{2}, \mathrm{~nm}\right)$ $\lambda_{\max }: 240,265,335,348,354 .{ }^{1} \mathrm{H} \mathrm{NMR}\left(300 \mathrm{MHz}, \mathrm{CDCI}_{3}\right)$, $\delta_{\mathrm{H}}(\mathrm{ppm}): 3.62\left(\mathrm{~s}, 6 \mathrm{H}, \mathrm{CH}_{3}\right), 0.795\left(\mathrm{~m}, 6 \mathrm{H}, \mathrm{CH}_{3}\right), 1.19(\mathrm{~m}$, $\left.8 \mathrm{H}, \mathrm{CH}_{2}\right), 1.81\left(\mathrm{~m}, 4 \mathrm{H}, \mathrm{CH}_{2}\right), 3.84\left(\mathrm{~s}, 3 \mathrm{H}, \mathrm{OCH}_{3}\right), 6.95$ (d, $\left.4 \mathrm{H}, \mathrm{C}_{6} \mathrm{H}_{4}, J=6.9 \mathrm{~Hz}\right), 7.55\left(\mathrm{~d}, 4 \mathrm{H}, \mathrm{C}_{6} \mathrm{H}_{4}, J=6.9 \mathrm{~Hz}\right) .{ }^{13} \mathrm{C}$ NMR $\left(75 \mathrm{MHz}, \mathrm{CDCl}_{3}\right), \delta_{\mathrm{C}}(\mathrm{ppm}): 14.1\left(\mathrm{CH}_{3}\right), 23.2\left(\mathrm{CH}_{2}\right)$, $29.17(\mathrm{C}), 29.9\left(\mathrm{CH}_{2}\right), 36.7\left(\mathrm{CH}_{2}\right), 55.3\left(\mathrm{OCH}_{3}\right), 114.1(\mathrm{C}=$, cyclopropene), 118.4 ( $\mathrm{C}_{\text {ipso }}$ ), 124.2 (Ar), 130.2 (Ar), 159.1 $\left(\mathrm{C}_{\mathrm{ipso}}\right.$,). EM: m/z $364[\mathrm{M}]^{+}$Calc. for $\mathrm{C}_{25} \mathrm{H}_{32} \mathrm{O}_{2}: \mathrm{C}, 82.37 ; \mathrm{H}$, 8.85 (\%). Found: C, 82.37; H, 8.83.

\section{X-Ray Crystallography}

A suitable crystal of compound 10, 11, 14 and 19a (obtained by crystallization from hexane at room temperature) was rolled in epoxy resin and mounted on a glass fiber. Bruker Apex AXS CCD area detector X-Ray diffractometer was the instrument used for the determination. The data were first reduced and corrected for absorption using psi-scans, and then solved using the program SHELL-XS. All nonhydrogen atoms were refined with anisotropic thermal parameters and the hydrogen atoms were refined at calculated positions with thermal parameters constrained to the carbon atom on which they were attached.

\section{SUPPLEMENTARY MATERIALS}

Crystallographic data for the structural analysis have been deposited with the Cambridge Crystallographic Data Centre, CCDC No. 684321for the 2,3-bis(4methoxyphenyl)cyclopropenone 10, CCDC No. 684322 for the 2-ferrocenyl-3-(4-methoxyphenyl) cyclopropenone 11, CCDC No. 684323 for the 2-ferrocenyl-3-(naphthalen-1-yl) cyclopropenone 14 and CCDC No. 684324 for the 3,3dimethyl-1,2-bis(4-methoxyphenyl) cyclopropene 19a

\section{ACKNOWLEDGEMENTS}

This work was supported by the DGAPA (IN209106). We thank Toscano R. A., Nieves Z. S. M., Rios O. H., Velasco L., Huerta S. E., Patiño M. M. R., and Peña Gonzalez M. A. for technical assistance.

\section{REFERENCES}

[1] Breslow, R.; J. Am. Chem. Soc., 1957, 79, 5318.

[2] Breslow, R.; Haynie, R.; Mirra, J.; J. Am. Chem. Soc., 1959, 81, 247.

[3] (a) Krebs, A. W.; Angev. Chem. Intern. Ed. Engl., 1965, 4, 10; (b) Billups, W. In The Chemistry of the Cyclopropyl Group; Patai, S.; Rappoport, A. Eds.; Wiley Interscience: New York, USA, 1987; (c) Komatsu, K.; Yoshida, Z. In Methods of Organic Chemistry (Houben-Weyl); de Meijere, A. Ed.; Thieme: Stuttgart, Germany, 1996; Vol. E17d, pp 3079-3192.

[4] West, R.; Sad, A.; Tobey, S. W. J. Am. Chem. Soc., 1966, 88, 2488.

[5] (a) Tobey, S. W.; West, R. J. Am. Chem. Soc., 1964, 86, 4215; (b) Sargeant, P. B.; Krespan, C. G.; J. Am. Chem. Soc., 1969, 91,415; (c) Craig, N. C.; Fleming, G. F.; Pranata, J. J. Am. Chem. Soc., 1985, 107, 7324 .

[6] West, R.; Zecher, D. C.; Tobey, S. W.; J. Am. Chem. Soc., 1970, $92,155$.

[7] Komatzu, K.; Kitagawa, T. Chem. Rev., 2003, 103, 1371.

[8] (a) Breslow, R.; Chang, H. W. J. Am. Chem. Soc., 1961, 83. 2367; (b) Breslow, R.; Hover, H.; Chang, H. W. J. Am. Chem. Soc., 1962 84, 3168; (c) Kende, A. S. J. Am. Chem. Soc., 1963, 85, 1882; (d) Fohlisch, B.; Burgle, P. Tetrahedron Lett., 1965, 2661; (e) Fohlisch, B.; Burgle, P. Ann. Chem., 1967, 701, 67; (f) Yoshida, H.; Yagi, K.; Tamai, T.; Sano, H.; Ogata, T.; Matsumoto, K. Bull. Chem. Soc. Jpn., 1985, 58, 1073; (g) Yoshida, H.; Sano, H.; Ogata, T.; Matsumoto, K. Bull. Chem. Soc. Jpn., 1988, 61, 4341; (h) Komatsu, K.; Kitagawa, T. Chem. Rev., 2003, 103, 1371.

[9] Klimova, T. B.; Klimova, E. I.; Méndez, S. J. M.; Hernández, O. S.; Martínez, G. M. Eur. J. Org. Chem., 2005, 4406

[10] Klimova, E.; Klimova, T.; Ruiz, R. L.; Cinquantini, A.; Corsini, M.; Zanello, P.; Hernández, O. S.; Martínez G. M. Eur. J. Org. Chem., 2003, 4265 . 